Corrigendum

\title{
Corrigendum to "Sphingolipids as Mediators in the Crosstalk between Microbiota and Intestinal Cells: Implications for Inflammatory Bowel Disease"
}

\author{
Bryan Phillips-Farfán, ${ }^{1}$ Karla Carvajal, ${ }^{1}$ Edgar Alejandro Medina-Torres, ${ }^{2}$ \\ Sara Elva Espinosa-Padilla, ${ }^{2}$ Gemma Fabrias, ${ }^{3}$ and Luz Camacho ${ }^{1}$ \\ ${ }^{1}$ Laboratorio de Nutrición Experimental, Instituto Nacional de Pediatría, 04530 Ciudad de México, Mexico \\ ${ }^{2}$ Unidad de Investigación en Inmunodeficiencias, Instituto Nacional de Pediatría, 04530 Ciudad de México, Mexico \\ ${ }^{3}$ Research Unit on Bioactive Molecules, Department of Biomedicinal Chemistry, \\ Institute for Advanced Chemistry of Catalonia (IQAC-CSIC), 08034 Barcelona, Spain
}

Correspondence should be addressed to Luz Camacho; camacho.luz@gmail.com

Received 5 October 2016; Accepted 20 October 2016

Copyright (C) 2016 Bryan Phillips-Farfán et al. This is an open access article distributed under the Creative Commons Attribution License, which permits unrestricted use, distribution, and reproduction in any medium, provided the original work is properly cited.

In the article titled "Sphingolipids as Mediators in the Crosstalk between Microbiota and Intestinal Cells: Implications for Inflammatory Bowel Disease" [1], reference [28] was incorrectly added as follows:

[28] "Y. Chen, S.-C. Xu, and R.-D. Duan, 'Mevalonate inhibits acid sphingomyelinase activity, increases sphingomyelin levels and inhibits cell proliferation of HepG2 and Caco-2 cells', Lipids in Health and Disease, vol. 14, no. 1, article 130, 2015."

It should be replaced with the following reference:

[28] "Chen Y, et al. Enhanced colonic tumorigenesis in alkaline sphingomyelinase (NPP7) knockout mice. Mol Cancer Ther, 14:1, 259-67, 2015."

\section{References}

[1] P.-F. Bryan, C. Karla, M.-T. Edgar Alejandro, E.-P. Sara Elva, F. Gemma, and C. Luz, "Sphingolipids as mediators in the crosstalk between microbiota and intestinal cells: implications for inflammatory bowel disease," Mediators of Inflammation, vol. 2016, Article ID 9890141, 11 pages, 2016. 


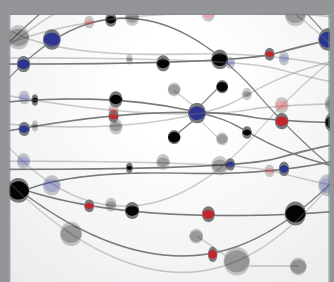

The Scientific World Journal
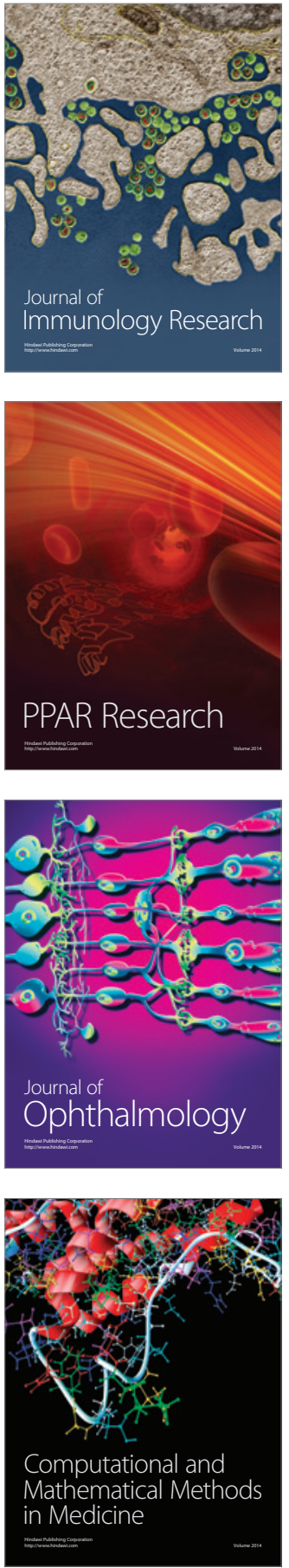

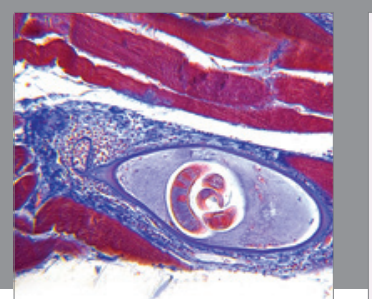

Gastroenterology Research and Practice

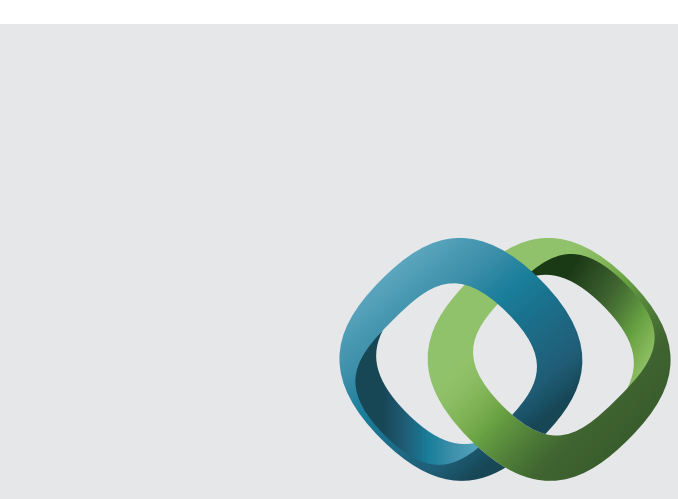

\section{Hindawi}

Submit your manuscripts at

http://www.hindawi.com
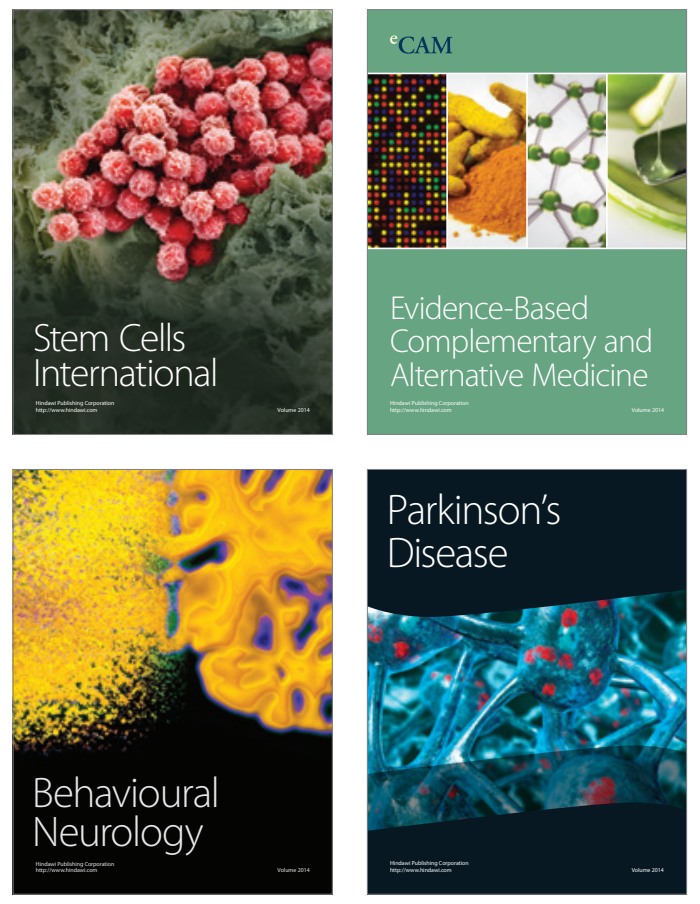
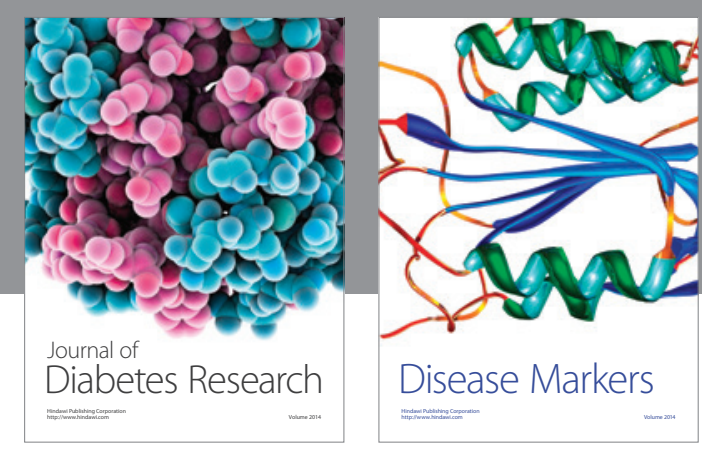

Disease Markers
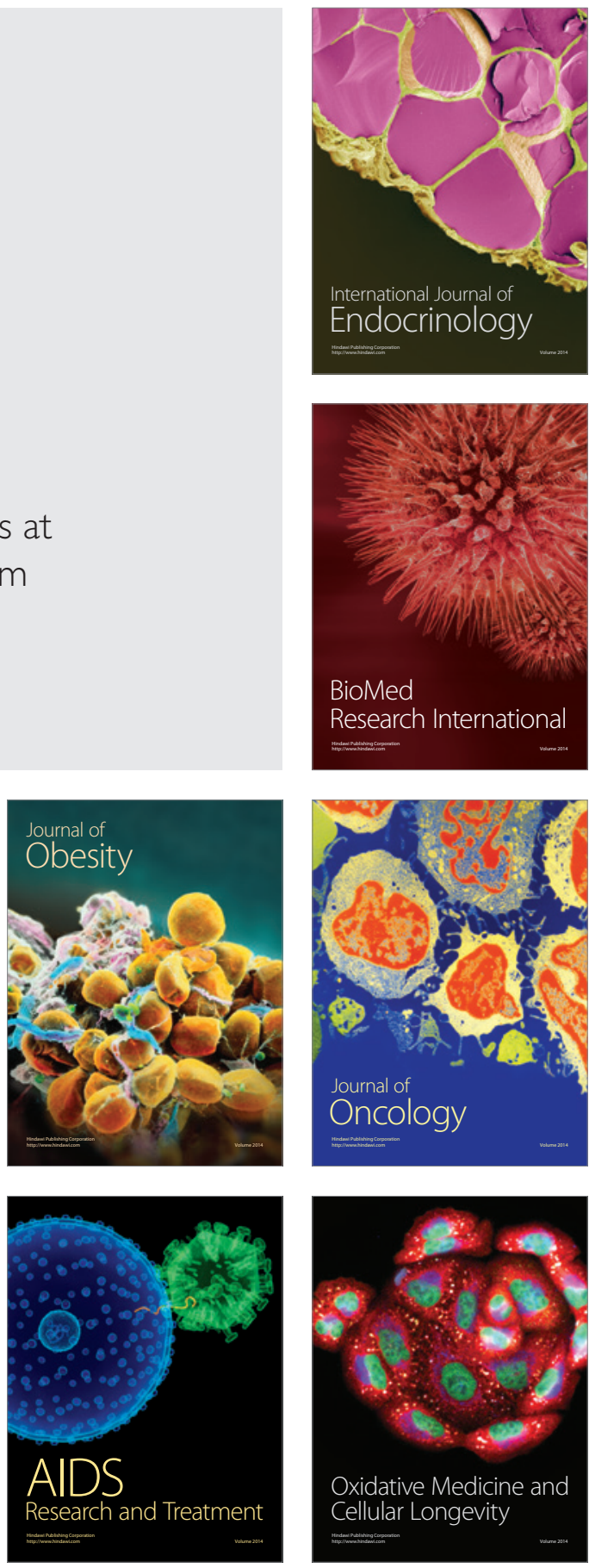